\title{
Diabetic retinopathy: new pharmacological targets
}

Running title: new insights for diabetic retinopathy

Francesca Lazzara ${ }^{1}$

${ }^{1}$ Department of Biomedical and Biotechnological Science, University of Catania, Catania, $\therefore$ 긱y

\section{Abstract}

Diabetic retinopathy (DR) is a secondary complication of diabetes mellitus $\mathrm{c}$ nd epr esents the most common cause of irreversible vision loss in working people of industria." ${ }^{2} \mathrm{e}_{\mathrm{i}}$ countries. DR is generally considered a microvascular complication of diabetes, a ' component plays a key role. The main cause of vision loss in diabotic, atients with proliferative diabetic retinopathy (PDR) is the diabetic macular edema (DME), ná is responsible to the retinal detachment. DME is mainly caused by new angiogenesis, which is a hc "mark of the advanced stage of DR (proliferative diabetic retinopathy, PDR). Retinal neovecc.larization is principally driven by pro-angiogenic factors (e.g., VEGF-A, PIGF), inflam, $r a_{\imath} \imath v$ mediators (TNF- $\alpha$, interleukins, chemokines) and oxidative stress-related elements. C'-ronic hyperglycemia is the primary causative factor of DR, however, several points of DR etiopathı qer esis are still unclear. Many other factors are involved during the early stages of DR such i $s t_{1}$ ? retinal hypoxia, that is a trigger of VEGF release in the back of the eye. Up to now, the nnc. "macological approaches for DR are intravitreal anti-VEGF agents and corticosteroids. Howt or. some patients can be refractory to anti-VEGF therapy, therefore, efforts must be carried DR. Hereby, the current literature will be revi ied about novel potential pharmacological targets, with a focus on PIGF, miRNAs and purin rgic P2X7 receptor. Future drug development campaigns on these targets might lead to better . lir.، al outcomes, possibly in the early phase of the disease.

\section{Keywords}

Diabetic retinopathy, anyinqt $\urcorner^{\circ}$ is, hypoxia, anti-VEGF, inflammation

\section{Impact statement}

Currently, manageı ' ent and treatment of diabetic retinopathy (DR) are characterized by several unmet medic $\lambda_{1}$. seds. Particularly, early-stage DR lacks of approved therapeutical intervention, and its pathog ${ }_{-1}$, गSו is multifactorial. Pharmacological research should focus on novel pharmacological target. thi ${ }^{+}$address pathogenetic factors of DR, such as inflammation, oxidative stress and any" "y? r. ’sis.

\section{Introduction}


Diabetic retinopathy (DR) represents a major public health concern, and it is the leading cause of vision loss in working age (1). The prevalence of DR among diabetic patients is about $40 \%$, and approximately $5-10 \%$ of these individuals have vision threatening conditions $(2,3)$. C'ronic hyperglycemia is the primary causative factor of diabetic retinopathy, however, etiopathonars sis of DR is still unclear (4-7). Ophthalmologists classify diabetic retinopathy mainly into iwn _ tar,es, the non-proliferative diabetic retinopathy (NPDR) and proliferative diabetic retinopathy ( $\mathrm{TR}$ ) (8). The NPDR is characterized by lesions due to chronic hyperglycemia, that can lead tc $r$ ic ioaneurysms due to instability of capillary walls. As soon as microaneurysms start leaking, $\Lambda$ DDF can develop in macular edema and consequent impaired vision, due to deposition of fluid na $r$ the macula. The presence of this fluid, composed by lipids, leads to the formation of $y_{c}$ low deposits, called hard exudates. Moreover, with the progression of the disease, the affected vt sels can be obstructed, then leading to impaired retinal perfusion. Retinal ischemia can caus e $u \geqslant$ infarction of the nerve fiber layer, resulting in fluffy and white patches, called cotton wool spots ( $(1 / S)$. Main cause of NPDR to PDR progression is represented by an extensive retinal ischem/c. (9), which promotes vitreoretinal neovascularization. In fact, the retina is a high oxygen ${ } z_{2}$.'ar ding tissue; under ischemia, cells release angiogenic factors, like vascular endothelial çrowth lactor (VEGF-A) and placental growth factor (PIGF), which promote neovascularization. Th 'se , essels are typically fragile, fenestrated, brittle and leaky. Leaking vessels can cause vitreou ; r.e norrhages, which are associated with gliosis and fibrovascular scar formation. Moreover, con : $7 r$ tion of fibrous tissue can result in tractional retinal detachment and sudden loss of visioı, (10,11), along with further activation of pro-fibrotic pathways. As soon as extensive vitreous $h \in \mathrm{r}$. or hage occurs, the PDR patient is considered at highrisk of vision loss due to retinal detachn ent 4,12 ). In case diabetic retinopathy affects the macula, the disease is also termed 'diabetic $n$ acliopathy'. Vascular leakage at the macula leads to macula swelling (diabetic macular edema $D v^{*}$ ), which is the most common cause of blindness in diabetic patients $(13,14)$. DME is most prevalent during PDR, following progressive vascular and neural damage (15). Diabetic DM- raı be classified as 'ischemic' or 'non-ischemic', based on the

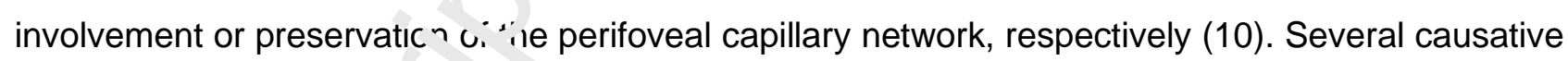

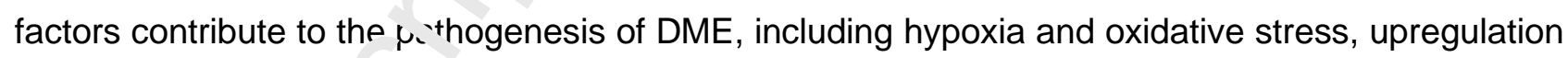
of VEGF-A, alteration 、 $f$ tr a blood-retinal barrier (BRB), retinal vessel leukostasis, pericyte loss, and vascular hyperperr...ar ility $(16,17)$.

\section{The re ' I. $^{\prime}$ neurovascular system as a basis to understand diabetic retinopathy}

The re ina is the innermost light-sensitive tissue of the eye, able to convert light to electrochemical signals, at first through photoreceptors, that transmit electrochemical signals to retinal neuronal circuitry (bipolar, amacrine cells). Neuroretinal electrochemical stimuli are thereafter processed and 
collected by retinal ganglion cells (RGCs), that transmit signals to the visual cortex by means of the optic nerve, that is constituted by RGCs axons $(18,19)$. The retina is characterized by a complex vascular system, whose integrity is necessary for the correct retinal function, providing nutrif. . $c$ and oxygen to the inner and outer retina (1). The retinal vascular system, similarly to central $r^{\text {rvous }}$ system, is characterized by blood-retinal barrier (BRB), which maintains the right millian T', BRB includes the inner and outer components. Inner BRB (iBRB) is characterized by junci ins between endothelial cells (ECS) and supporting pericytes and astrocytes; while in the out $2 \mathrm{r}$ bRB (oBRB) junctions are between retinal pigmented epithelial cells (RPE) $(20,21)$ (Figurn 1) Die jetes can affect both iBRB and oBRB before and after neovascular events, involving endotr lia $^{\prime}$ cells, pericytes (at the capillary level), vascular smooth muscle cells (arteriolar/arterial leve, , qlia neuronal processes, associated immune cells, and if choroid is affected, also RPEs (22).

Pericytes, endothelial cells and iBRB

Depletion of pericytes is a hallmark of DR. Pericytes wrap car."'7ry walls and share basal lamina with endothelial cells, with which they directly interact $t$ ' $\mathrm{rn}$ $\mathrm{xh}$ J-cadherin and connexin-43 hemi channels $(19,23,24)$. Pericytes wrap around retinal capi'!aries providing structural support, modulation of endothelial cell function and homeosta IS. in the inner BRB, retinal endothelial cells form the physical barriers between vascular lum $\_n$ and the retina. Retinal endothelial cell-cell junctions include tight-, adherens- and gap-jun: inn. that regulate several cell functions such as migration, growth, protection from cell deat ${ }^{\prime}$ ( $n_{1}$ crosis, apoptosis) and damage (inflammation, ischemia) $(19,25)$.

Retinal glia and neurons

Retinal glial cells, including Müller = $\|_{1}$ and astrocytes, provide metabolic support to neurons and play a critical role in iBRB homeosta ic and integrity $(26,27)$. Moreover, Müller cells regulate glucose flux between the circulation arı vetinal neurons and have a role in providing substrates for aerobic metabolism in neurons ky g. 'col eogenesis (28).

\section{Immune cells}

The develok nerı of new blood vessel is also supported by microglia, monocyte-derived tissue macrophi $g r, s$ of the central nervous system. Interestingly, retinal microglia is present in the retina before $y_{t}$ 'e.lopment of vascularization (29). In the adult retina, ramified microglia cells were found in the $ı$. ne , and outer plexiform layers, and are able to produce factors that support neuronal survival. Several types of trauma or insults lead to microglia activation, characterized by amoeboid morphology transition and production of pro-inflammatory cytokines (30). 

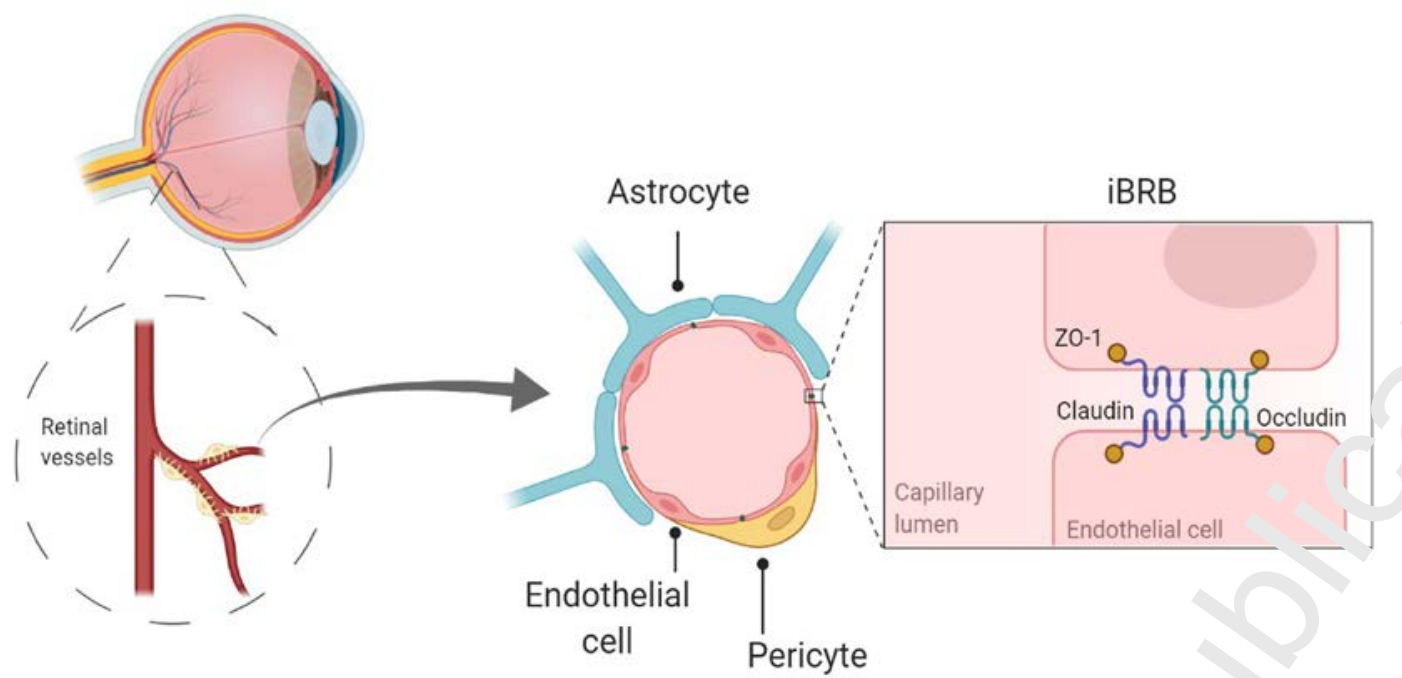

Figure 1. The neovascular unit. In a healthy retina, vessels ar stı Ictured by endothelial cells closely associated with pericytes, maintaining the function of the innt. ',lood retina barrier (iBRB). In particular, adjacent endothelial cells are connected by tight junr ions and adherens junctions.

Nowadays, the improvement of the research methoc'nlogies allows us to mimic, in vitro, the real complexity of the ocular structures and barriers. Rec entı,, two labs (Wisniewska-Kruk et al. and Fresta et al.,) set up two different in vitro BRB modf is s sed on a triple co-culture of retinal cells, the first research's group used bovine cells, the secu $\uparrow$ research's group used human cells. Fresta et al. used human retinal pericytes, astrocytes $a_{1} \gamma$ eldothelial cells to mimic the human BRB with the same cellular layer order and the same nur $f_{i} i \mathrm{ic}$ al ratio. This in vitro paradigm is useful to study and investigate the molecular mechanism $r$ !lat $\rfloor$ to DR, and to test new pharmacological molecules $(31,32)$

\section{Pathophysiology of ، riak etic Retinopathy}

The pathogenesı c: DR is complex and involves multiple interlinked mechanisms, including metabolic morific :t: ons, mitochondrial dysfunction, vascular damage, apoptosis, inflammation, and oxidative stre $=(33-36)$. Several pathways have been proposed to better understand microvascular compl: rat.c is during DR along with sustained hyperglycemia: e.g. accumulation of advanced glyratio' und-products (AGEs), inflammation, activation of protein kinase C and neuronal dysfur:tion $(19,37)$. All these pathological modifications lead to increased vascular permeability and capillary depletion, resulting in macular edema and retinal neovascularization. 


\section{Hyperglycemia and Retinal Microvasculopathy}

One of the earliest abnormalities observed in DR is related to retinal blood vessels, with the constriction of arteries and arterioles and blood flow anomalies (38-40). Vessel abnormalit. 's rtsult in a series of metabolic and biochemical alterations, like: (i) induction of activation of $s$ गve

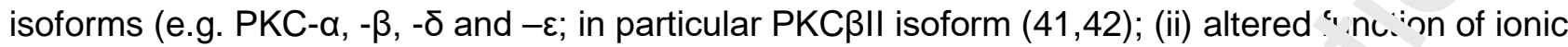
channels in smooth muscle cells (BK channels) present in the retinal arteriolar vas 4 - ?ture (43-45). As mentioned before, retinal pericytes loss is another hallmark of the early ever.cs $0_{1} \mathrm{JR}$. Several in vitro and in vivo studies report that hyperglycaemia leads to pericyte loss $(? 4, \therefore, 4 i)$ or degenerated pericytes, also called "ghost cells". Therefore, pericytes loss leads to endc'í 'liai cells degeneration, microvascular destabilization and perfusion alterations with consequc $n t$ i vemic events due to capillary occlusion $(38,48-50)$. On this regard, pericyte-like differentiatı.? , f human adipose-derived mesenchymal stem cells (hASCs) has been recently proposed $\&$ r,utative therapeutic tool for restoring damaged BRB (51).

\section{Retinal Inflammation}

Several studies were focused on the role of inflammato: ' processes in early stages of DR, although, inflammatory mechanisms are still poorly understona. C'ironic low-grade inflammation has been detected in different stages of DR, both in diabetic $c^{r} . \mathrm{m}$ Al models and in patients $(52,53)$, along with increased systemic and local expression i Dıvinflammatory cytokines (54). In particular, microvascular endothelium, activated by thers $\iota$; okines and angiogenic growth factors, expresses pro-inflammatory molecules (e.g., IL-1 $\beta \mathrm{I}_{\mathrm{L}} \cdot \mathrm{\epsilon}, \mathrm{TNF}-\alpha$, high-mobility group box-1 (HMGB1)) and chemokines (MCP-1), involved in $\mid \rho_{1} 1_{1} \cdot n \gamma_{j}$ fte recruitment and activation (55-57). Leukocyte-

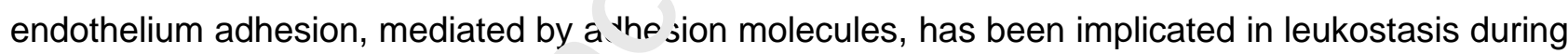
diabetes. Sequential adhesive int $\epsilon$ ic ct uns between endothelial cells and leukocytes, are modulated by adhesion molecules (e.g. 1. AM-1) present in the surface of endothelial cells, which interact with the leukocyte counter-recer cor :D18 $(58,59)$. All these inflammatory responses may contribute to neovascularization in th: rtim during DR, especially under hypoxic conditions. Furthermore, increasing data sugge, $\mathrm{s}$ a, $\mathrm{u}$ ucial role of tool like receptors (TLRs) in the pathogenesis of DR; indeed, TLR4 expression is, sir pathways (60). A. r $\epsilon_{y}$ ards the biochemical pathways involved in DR, expression of inflammatory cytokines mignht $\mathrm{w}$ - mediated by activation of mitogen-activated protein kinases (MAPKs) (61), as well as ERKs, normally involved in several cellular processes (62). ERK pathway can influence NF$\mathrm{KB}$ activa.ic $\mathrm{n}$, oy the regulation of NF-KB-dependent genes expression, e.g. inducible nitric oxide syrthas ( (ivOS), cyclooxygenase-2 (COX-2) and tumor necrosis factor-alpha (TNF- $\alpha$ ) (63).

\section{Retinal Hypoxia}


The retina is one of the most oxygen and glucose demanding tissue (64). Retinal hypoxia represents an important causative factor for DR development, and plays a central role in progression of NPDR to PDR, due to the release of some soluble mediators such as cytokines, chemokine and yrowth factors which promote the growth of extraretinal neovascularization (65). Ocular ischemic ${ }^{\prime \prime} \epsilon_{1}{ }^{+} s$ are

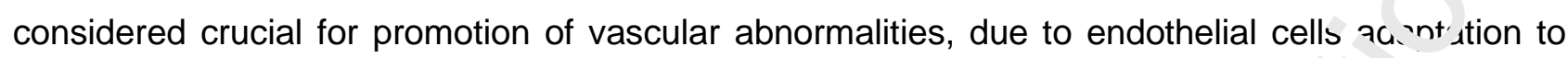
stress, which upregulate several genes, like VEGF (66). Furthermore, VEGF and c.her hypoxiaregulated growth factors, are controlled by hypoxia-inducible factor (HIF) (67). HIF i, a neterodimer, HIF-1 $\alpha$ (inducible subunit) and HIF-1 $\beta$ (constitutively expressed). Oxygen d $p$ pr. ratic $n$, induces HIF$1 \alpha$ to translocate into the nucleus and to bind the hypoxia-response ele $a_{1} r_{1}$; (HREs) in DNA, leading to expression of inflammatory and pro-angiogenic genes, pi not $\mathrm{ng}$ inflammation and angiogenesis, respectively $(68,69)$.

\section{Retinal Angiogenesis}

Angiogenesis is a crucial mechanism in physiological vascular a 'elopment and during pathological conditions. Angiogenesis is related to proliferation of endc $h \in$ ial $c$ alls (ECs) that, stimulated by some angiogenic factors, generate new blood vessels (70) Indee 4 , this process is characterized by the angiogenic growth factors, which activate the recepto $s \mu$ ?sent on resident ECs; then, endothelial cells begin to release specific enzymes such as $m_{x} \mathrm{tr} \times$ metalloproteinases (MMPs) which degrade the basement membrane, leading ECs to leave. a uı uginal vessel wall. After that, endothelial cells start to proliferate into the surrounding matrix, har 's to the adhesion molecules (Figure 2).

(1) Angiogenic stimuli

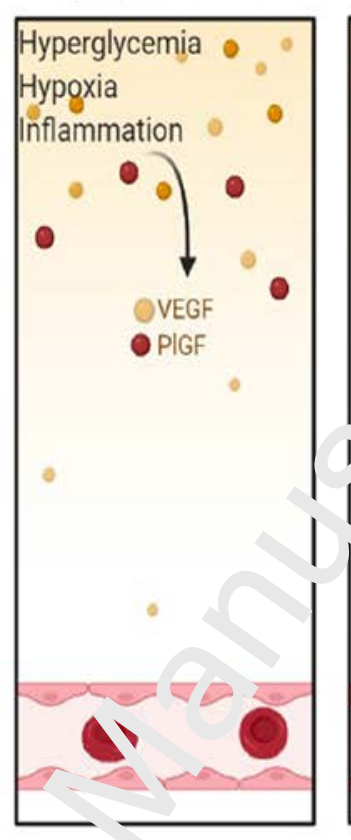

(2)

Tin sell competition
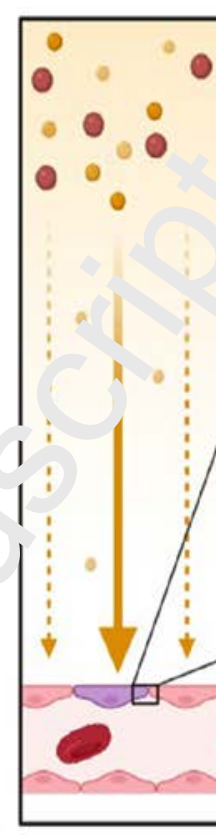
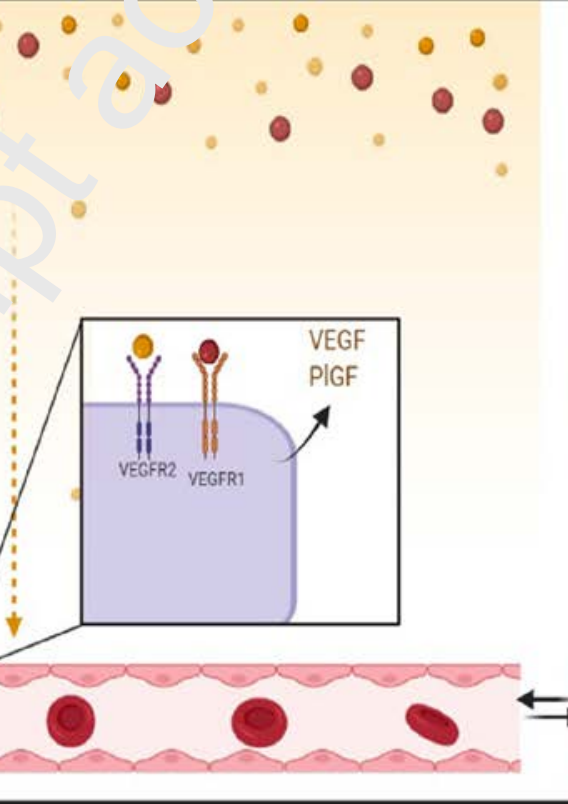

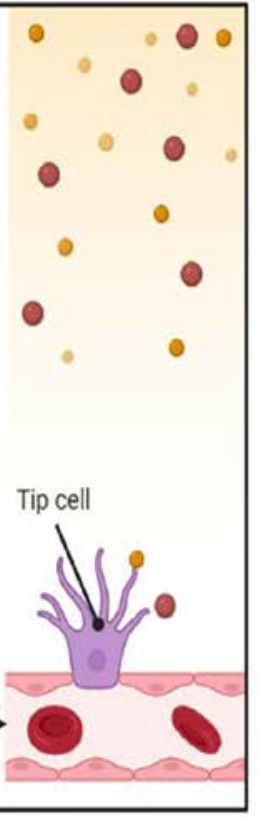

(3)

Sprouting

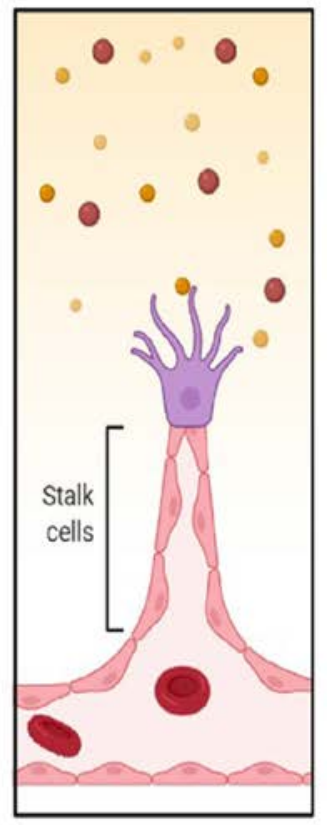

Figure 2. Retinal angiogenesis in diabetic retinopathy. Angiogenic factors (i.e., VEGF and PIGF) stimulate angiogenesis in tissues. VEGF/PIGF bind to VEGFR-2/VEGFR-1 on the surface of 
endothelial cells (ECs), triggering competition between neighboring cells as they differentiate. In normal intact retinal vessels, blood flow is regular and the vascular configuration is stable. However, in diabetic retinopathy, this process is strongly exacerbated by several phenomena, such as hyperglycemia, hypoxia and inflammation. The expression of angiogenic factors is increar, 1 and the growth of new blood vessels is uncontrolled. The neovascularization is typical of the late: stages of diabetic retinopathy, with the formation of new unstable vessels. This leads to vascul ${ }_{\lambda}$ c $i$ innage, loss of endothelial tight junctions, pericyte detachment and basement membrane thick $\epsilon_{\text {. }}{ }^{i n}{ }^{\prime} j$ (iBRB breakdown).

The main regulators of angiogenesis are the vascular endothelial growth factors $N E$ EF-A, VEGFB, VEGF-C, and VEGF-D) and the placental growth factor (PIGF) (71-76). VEC Fs i an bind to three tyrosine kinase receptors: VEGFR-1 (Flt-1), -2 (KDR), and -3 (Flt-4) ( $1 ?$ ! . 'EGFR-1 (78) and VEGFR-2 (79-81) are the main receptors involved in angiogenesis. VEL':R-८ (also known as Flk1) is expressed on endothelial cells. Binding to VEGFR-1 (also known as $\mathrm{r}^{\prime}{ }^{1}$ ) leads to the activation of quiescent endothelial cells and promote vascular permeability ( $><-35$ ). VEGF-A is significantly increased in ocular tissues from patients with diabetes (86). All $t_{1}$, mechanisms linked to the progression of DR, are responsible of the overproduction of $v_{-}-G F-A$, including hypoxic events. Besides stimulation of endothelial cell growth, VEGF- I $c$ n ilso promote the disassembly of junctions between endothelial cells, leading to vasculer permtability (BRB breakdown).

\section{Fibrosis}

Angiogenesis and subsequent fibrotic events occ. ${ }^{r}$ viul progression of PDR. Fibrosis can cause the formation of fibrovascular epiretinal membr: nes which lead to retinal complications such as tractional retinal detachment and, at last $V^{\prime}$ 'sion 'oss (87-89). Fibrosis is a complex reparative process that is activated to restore dar agex tissue, by means of remodelling extracellular matrix (ECM). Cell proliferation, ECM depos ison and neovascularization are key mechanisms during PDR, usually stimulated by pathological « nuicions like hypoxia or inflammation, promoting formation of fibrotic tissue $(90,91)$. Along with $\mathrm{m}^{\circ}{ }^{\circ}$ oglia and astrocytes, Muller cells in response to retinal injury participate to fibrotic events, thro ``ר production of inflammatory and angiogenetic mediators $(92,93)$. Fibrosis can also be proi.nnl $\gamma h$, retinal hypoxia, leading to a consequent overproduction of VEGFA (94-96). Several grow $>$ faciors play a role in fibrosis, such as transforming growth factor- $\beta$ (TGF$\beta$ ), platelet-derived $g$ owt $\mathrm{I}$ factor (PDGF), and the pro-fibrotic connective tissue growth factor (CTGF) (97-99). P • ஃ əly, increased levels of CTGF were found in the vitreous of patient with PDR $(100,101)$ and it has heen supposed that CTGF could be a downstream mediator of TGF- $\beta$, the main regulator of $\mathrm{cro}$ - ihrotic effects.

\section{$\mathrm{Ph}$-maiological treatment of DR}

Currently, only PDR can be pharmacologically treated, and no approved treatments are available for NPDR. As mentioned above, the hallmarks of this disease are the abnormal vessel growth in retinal 
area, up-regulation of inflammatory factors, and the breakdown of the blood-retinal barrier (Figure $3 A)$. Clinical history of PDR has been revolutionized with anti-angiogenic treatments, that are invasive and expansive. Along with the anti-VEGF agents (34), anti-inflammatory drugs ‘ also used (102). Steroids are potent drugs to quench inflammation and reduce edema, fibrin ranc-ition, capillary hyperpermeability and phagocytic migration typical of the inflammatory resn nor, (103105). Furthermore, they also counteract the action of VEGF-A (106). Three cortic steroids are actually approved to handle diabetic macular edema (DME): dexamethasone (LEX) fluocinolone acetonide (FA) and triamcinolone acetonide (TA). The limitation of these dri'gs $s$ re ated to the side effects such as cataract and rise in intraocular pressure (102).

\section{Anti-VEGF therapy}

The anti-VEGF therapies have revolutionized the treatment of $D 2$. These medications, such as ranibizumab (Lucentis, Genentech) and aflibercept (Eylea, Reg^neroı,' called vascular endothelial growth factor inhibitors (anti-VEGF), have a consolidate histrn! .. terms of efficacy and safety for the treatment of DME.

Ranibizumab is a 48kDa antigen-binding fragment ( $F r \cdot N$, of a humanized monoclonal antibody with

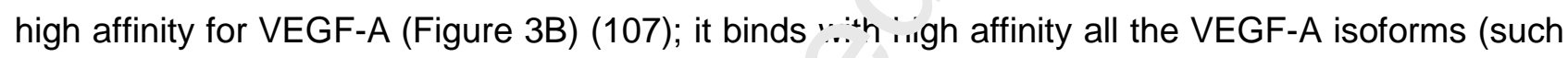
as VEGF-A $A_{165}$, VEGF-A $A_{110}$ and VEGF-A $\left.A_{121}\right) r e^{\prime} I_{1} \sim$ the activation of VEGFR-1 and VEGFR-2 receptors. The small size of this fragment enh $x \mathrm{n} c \mathrm{~s}$ its diffusion from the vitreous to the retina and the choroid, improving the pharmacokinetic I Jfllc. compared to bevacizumab (108).

Aflibercept has been approved by Food znd Jrug Administration (FDA) in 2011 for the treatment of age-related macular degeneration ( $/ \mathrm{MD}$, for impaired vision due to secondary macular edema, caused by retinal vein occlusion ( $3 r_{\lambda_{1}}=h$ RVO or central RVO, Retinal vein occlusion) and for the treatment of visual impairmsnt due to myopic choroidal neovascularization (CNV choroidal neovascularization). Recent'y, flivercept was also approved for the treatment of diabetic macular edema. Aflibercept (VEGF +rar; is a fusion protein $(115 \mathrm{kDa})$ bearing two binding domains of VEGF receptors (Figure 3B) (10s; Moreover, aflibercept's binding affinity to VEGF-A $A_{165}$ is almost 100-fold greater than ranibizı $\min _{1} \mathrm{~h}$ and bevacizumab (110-112), and is the only anti-VEGF agents that binds PIGF, although with In'ser affinity (38.9 nM dissociation constant - KD), compared to VEGF-A (0.49 nM dissociation : nn ;tant - KD) (113).

Conbercer: (Lu nitin) is a $141 \mathrm{kDa}$ recombinant fusion protein composed of the second Ig domain of VEGF $: 1, n d$ the third and fourth Ig domains of VEGFR-2, fused to the constant region (Fc) of hu: . in liG1 (Figure 3B). Considering the increasing need for less frequent intravitreal injections of anti- VLGF, conbercept has designed to improve dose regimens and compliance. Similarly to aflibercept, conbercept has multiple targets (114). 
In 2021 FDA approved the faricimab (Roche) with the following indications: wet AMD and DME. This antibody targets two different pathways involved in progression of these retinal diseases: angiopoietin-2 (Ang-2) and vascular endothelial growth factor-A (VEGF-A) (Figure 3B). Fr..;-imab showed positive results across four phase III studies in AMD and DME. Faricimab clinir.a. trials proved a non-inferiority efficacy evidence, compared to aflibercept $(115,116)$.

Brolucizumab (Beovu, Novartis), recently approved in US and EU, is a humarizt 1 single-chain

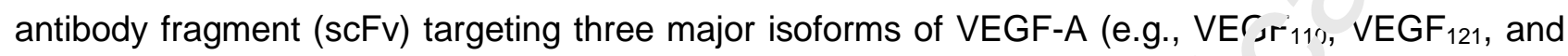
VEGF $_{165}$ ) (Figure 3B). Compared with other VEGF-A inhibitors, brolucizur ab : sı ılller (26kDa). In

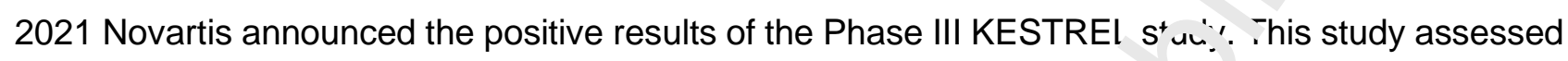
safety and efficacy of $6 \mathrm{mg}$ brolucizumab in patients with DME.

Although most of patients show beneficial effect by the approved ani. VEGF agents, a significant percentage of people are poor responders. To overcome this urı net medical need, NovaGo Therapeutics is developing a first-in-class fully human antiborı, $\mathrm{L}_{1}$. गrapy with a novel mechanism of

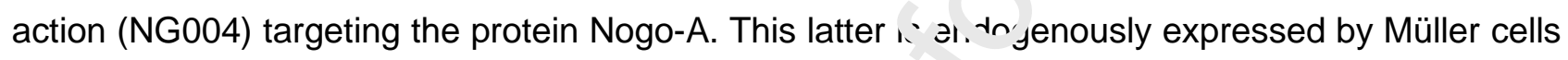

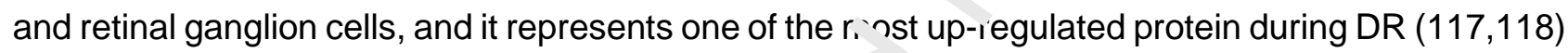
(Figure 3B). It has been demonstrated that the block of $t$ is protein could lead to the reduction of angiogenesis and inflammation, as already dem orst ated in an in vivo model of retinal injury (excitotoxicity-induced neuroinflammation) (119) 
A
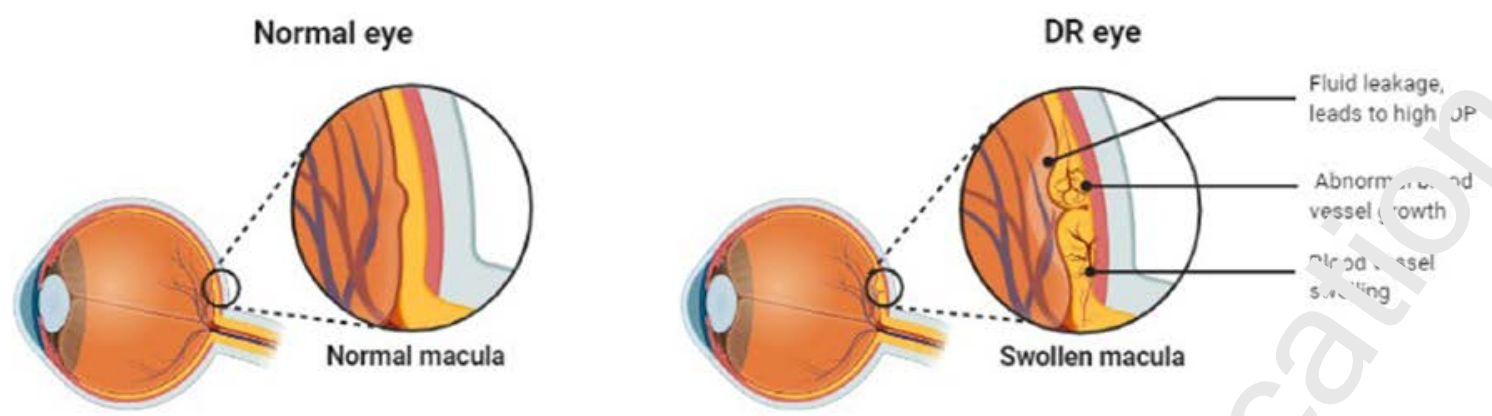

B

Pharmacological treatment

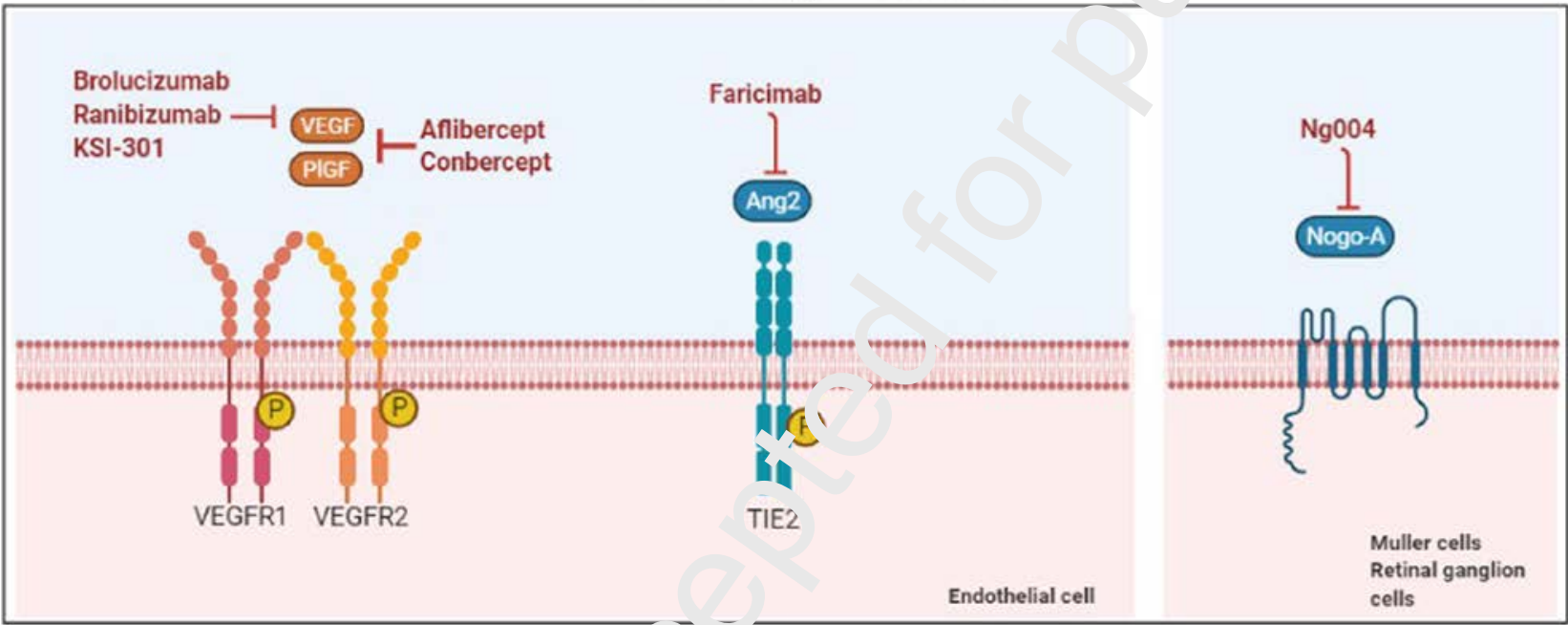

Figure 3. Diabetic retinopathy clini :al rallmarks and treatments. (A) Diabetic retinopathy is the leading cause of vision loss in diar _ ${ }^{+i} c_{\text {n }}$ atients and is characterized by abnormal vessel growth in retinal area, inflammation, breakd $u n$ of the blood-retinal barrier and fluid accumulation. (B) Therapeutic strategies targe ${ }^{\prime \prime} \mathrm{g}$ different signalling pathways involved in the pathogenesis of proliferative DR and diabetic ... ? ${ }^{\mathrm{C}} \mathrm{u}$ เar edema.

As regards the safet, pr file of intravitreal anti-VEGF agents some adverse reactions such as endophthalmitis, in r.uc ular inflammation, intraocular pressure elevation and ocular hemorrhage are sometimes assncial . I with the treatment, (120-122). Besides that, VEGF protein has a physiological role in the re in $a$, so the prolonged period of treatment with these compounds could be deleterious (123). Mo' $e_{1}^{\prime} \mathrm{e}_{1}$, these agents have a short half-life, and the widely treatment schedule is the treatand-e, ' na . . gimen with several injections for several months. For these reasons new agents and inn 'ai.' delivery systems are under investigation. 


\section{Novel molecular targets}

\section{Placental Growth Factor (PIGF)}

PIGF has been implicated in pathological angiogenesis, especially in retinal disorders, alth، ' Igh its function is less well understood (85), compared to VEGF-A. Oppositely to VEGF-A. . JGF is not required during physiological angiogenesis but plays a role only during patholoc, $\neg$ al conditions $(82,83,112,124-128)$. Secreted PIGF specifically acts through VEGFR-1. Further $n$ 'sr , it has been showed that VEGF-A and PIGF can form heterodimers (129) which can bind bot' VEGFR-1 and VEGFR-2, stimulating endothelial cells migration and vasorelaxation via $\therefore$ '? , itric oxide pathway $(130,131)$. Moreover, it has been found that VEGF/PIGF heterodimei ? $x$, ? ad to activation of a positive feedback and overproduction of VEGF-A, which binds also the $v^{\prime}=G F R-2$. Therefore, PIGF may stimulate angiogenesis directly through VEGFR-1 but als, 'nurectly through VEGFR-2 $(83,128)$. PIGF acts also through neuropilin receptor 1 (NRP1) $(124,1,7,132)$, that is expressed in angiogenic vessels $(133,134)$. As well as VEGF-A, PIGF is expre - sed by endothelial cells in hypoxic environment (135-137). The PIGF overexpression is driv $\mathrm{n}$. ' $\vee \mathrm{H} \cdot \mathrm{F}-1 \alpha$, which is able to recognize a hypoxia responsive element (HRE) located in the second intru 7 of PIGF gene (136). One interesting recent evidence demonstrated that aflibercept anc a -pecific anti-PIGF antibody exert antiinflammatory effects in the diabetic retina. Specificr.ıy, atlibercept and anti-PIGF antibody protected retinal endothelial cells (HRECs) and primary mo $\sim^{-}{ }^{-}$, ı tinal pigmented epithelial cells (mRPEs) from cell damage induced by high glucose levels, loc ing the activation of the ERK pathway with the subsequent suppression of TNF- $\alpha$ release $1^{\prime}$ '.'.

miRNAs

There is an increasing interest on m:-ro $-2 i v A s$ as putative biomarkers for the progression of DR (138). Platania et al., demonstrated that $\leqslant m$ ll set of miRNAs were dysregulated in serum and retina of diabetic mice. These miRNAs w re also dysregulated in serum of patients with diabetic retinopathy. In the in-vivo study, thes? $r_{1}$. RN Is modulated not only VEGF-A expression (up-regulation) but also the neurotrophic factor E JNr (down-regulated) (139). Moreover, Santovito et al., reported that DR is associated with higl er circulating levels of miR-25-3p and miR-320b and lower levels of miR-495$3 p$, in patients wi'n , ye 2 diabetes and diabetic retinopathy (140). Interestingly, it has been demonstrated a spc -itic association between miRNAs expression and hypoxic microenvironment; in fact, retinal $h_{y \boldsymbol{p}}$ 'xia led to the upregulation of six miRNAs (miR-20a-5p, miR-20b-5p, miR-27a-3p, miR-27b-2 $r$. $n_{1}$-206-3p, miR-381-3p) in human retinal endothelial cells. These miRNAs, are capak - to ir.terfere with the expression of genes belonging to the TGF- $\beta$ pathway at posttra. arin ional level. In fact, the dysregulation of these miRNAs has driven and promoted angioge,esis and fibrosis, through the modulation of VEGF-A, TGF- $\beta$ and HIF-1 $\alpha$, in retinal endothelial cells (135,141-144). Moreover, Shao et al. identified miR-136 and miR-374 dysregulation as hallmark of proliferative DR (145). The putative involvement of miRNAs in the 
pathogenesis of DR is also linked to the direct activation of the inflammatory pathway through the TLR-4, as well demonstrated in several in-vitro and in-vivo models of DR; in fact, different miRNAs are associated with the regulation of TLR-4 expression during diabetic retinopathy (140 148). Currently, evidence about post-transcriptional regulation of PIGF expression by miRNAc «s not been retrieved. A high-throughput screening of miRNAs potentially related to PIGF NOL' ' iddress this issue.

\section{P2X7 receptor}

In the last decade an important link between DR and purinergic receptor 1. ? 5 i en demonstrated, considering P2X7 receptor as a putative pharmacological target in thi_ retir, $\|$ disease (149-151). $\mathrm{P} 2 \mathrm{X7R}$ is a member of the family of purinoceptors, ligand-gated membra ne ion channels activated by extracellular ATP. This receptor is widely distributed in all $r f_{\text {ii. }}$ ? 1 rayers and also in retinal microvasculature. P2X7R stimulation promotes a wide range of $c_{1 .} \cdot$ rar responses, ranging from proliferation to cell death, from cytokines release to reactive oxv sn species (ROS) production. The early up-regulation and activation of P2X7R has been rf iati $d$ tr several types of retinal diseases, and its antagonism revealed benefits against inflammation, 0 , dative stress and angiogenesis, both in vitro and in vivo studies (152-156). In particule $c_{1} L_{1} ?$ selective antagonist of this receptor (JNJ47965567) has shown anti-inflammatory $: \pi$, rt, through the decreased activation of inflammasome and IL-1 $\beta$ production, in several $k_{c}{ }^{\text {thu }}$ ugical conditions. Moreover, P2X7R inhibition up-regulated the expression of junction protens in the iBRB, which is compromised in early DR $(156,157)$. Furthermore, it was found a siç nif.c nnı activation of P2X7R during retinal hypoxia, and the P2X7R blockade, by selective P2X7K : an+agonists A740003 and AZ10606120, inhibited the HIF$1 \alpha$ and VEGF-A retinal overexpressic $ı(1 \zeta \perp, 158)$. 


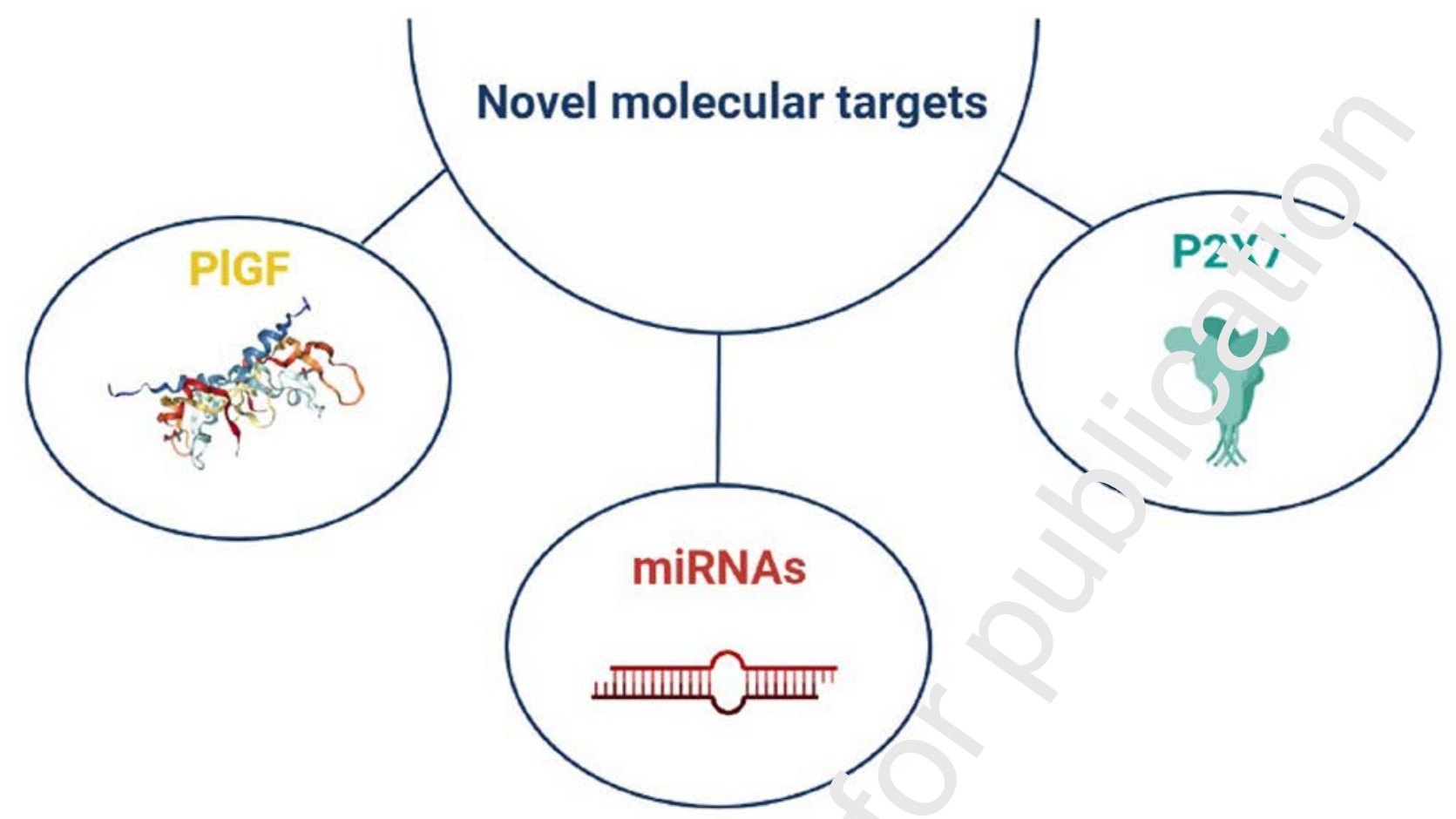

Figure 4. Novel molecular targets for the treatmenı of 'liabetic retinopathy.

\section{Conclusions}

Increasing evidence suggest that retinal $n \epsilon$, rn'segeneration and inflammation are implicated in the pathogenesis of diabetic retinopathy. covr,ral recent studies were carried out to explore new pharmacological targets, potentially $a \cdot v^{\prime} e^{+} \mathrm{J}$ counteract retinal neurodegeneration and inflammation. The present review summarizes if $w$, lints and puzzle pieces about the etiopathogenesis of DR, addressing several hypothest and trying to identify and validate novel and promising pathways implicated in this pathology Cu rently, the first-line pharmacological therapy for PDR and DME is

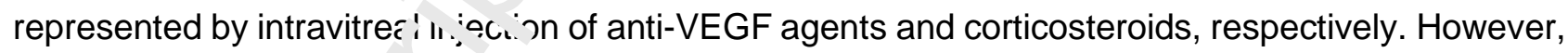
the current proliferativ', dian atic retinopathy pharmacotherapy is characterized by frequent, invasive

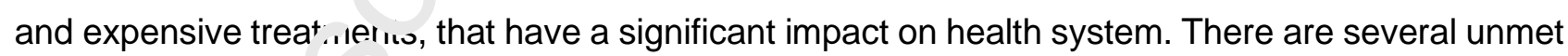
medical needs ir, the .nanagement of DR that stimulate the pharmacological research to develop novel pharmarnı _i jal targets and drugs to counteract the early phases of diabetic retinopathy. 
The authors declare that they have no conflict of interests.

\section{Acknowledgements}

This work was supported by the Italian Ministry of Economic Development (MISE) PON-Inı , רative $\mathrm{PhD}$ Program. The author would like to thank the Pharmacology section of the University of $\mathrm{C}$ atania, in particular Prof. Claudio Bucolo, Dr. Chiara Bianca Maria Platania and Dr. Fedc. ira Jonti for reviewing the manuscript.

\section{References}

1. Cheloni R, Gandolfi SA, Signorelli C, Odone A. Global prevalence л " „əuetic retinopathy: Protocol for a systematic review and meta-analysis. Vol. 9, BMJ no n. 2019; 9(3):e022188.

2. Ruta LA, Magliano DJ, LeMesurier R, Taylor HR, Zimmet PZ Thar. JE. Prevalence of diabetic retinopathy in type 2 diabetes in developing and de $>$ lor ed countries. Diabetic Medicine. 2013; 30(4):387-98.

3. Zhang X, Saaddine JB, Chou CF, Cotch MF, Cheng Y J, L eiss LS, et al. Prevalence of diabetic retinopathy in the United States, 2005-200, JMiviA - Journal of the American Medical Association. 2010; 304(6):649-56.

4. American Academy of Ophtalfmology. Preferreg Dr'^ctice Pattern® Guidelines: Diabetic Retinopathy. American Academy of Opghalr ir io jy. 2016.

5. Kashim RM, Newton P, Ojo O. Diabetic . $e_{\imath}$ ' nopathy screening: A systematic review on patients' non-attendance. International s' 'ir.lal of Environmental Research and Public Health. 2018; 15(1):157.

6. Maric-Bilkan C. Sex differences ir, mir io- and macro-vascular complications of diabetes mellitus. Vol. 131, Clin Sci (Lol d).乞̃o17;131(9):833-846.

7. Shukla U V, Tripathy K. Dia Jr.tic Retinopathy. StatPearls. Treasure Island (FL); 2022.

8. Tarr JM, Kaul K, Chopra i1. Kohner EM, Chibber R. Pathophysiology of Diabetic Retinopathy. ISRN C ıhtr, zlmology. 2013; 2013:343560.

9. Duh EJ, Sun JK, $\ulcorner$ titt $r$ i . Diabetic retinopathy: current understanding, mechanisms, and treatment stratf gles. JCl insight. 2017; 2(14):e93751

10. Stitt AW, Cu ti, - $-M$, Chen M, Medina RJ, McKay GJ, Jenkins A, et al. The progress in understana.. $\gamma$ and treatment of diabetic retinopathy. Progress in Retinal and Eye Research. 2016; 51:_ $\div 686$.

11. Lechne, 1, O'Leary OE, Stitt AW. The pathology associated with diabetic retinopathy. Vision Rejf ar _h. 2017; 139:7-14.

12. D D retsky L. Principles of diabetes mellitus. Principles of Diabetes Mellitus. 2010.

13. Wu L. Classification of diabetic retinopathy and diabetic macular edema. World Journal of Diabetes. 2013; 4(6):290-4. 
14. Wilkinson CP, Ferris FL, Klein RE, Lee PP, Agardh CD, Davis M, et al. Proposed international clinical diabetic retinopathy and diabetic macular edema disease severity scales. Ophthalmology. 2003; 110(9):1677-82.

15. Antonetti DA, Klein R, Gardner TW. Diabetic retinopathy. New England Journal of Mt ricine. 2012; 366(13):1227-39.

16. Chung YR, Kim YH, Ha SJ, Byeon HE, Cho CH, Kim JH, et al. Role of Inflamiı ?tioıı in Classification of Diabetic Macular Edema by Optical Coherence Tomograph ‘y z רurnal of Diabetes Research. 2019; 8164250.

17. Ascaso FJ, Huerva V, Grzybowski A. The role of inflammation in the nai 'ngenesis of macular edema secondary to retinal vascular diseases. Mediators $r:$ :'רı.mmation. 2014; 2014:432685.

18. Hoon M, Okawa H, Della Santina L, Wong ROL. Functional arcrin'ture of the retina: Development and disease. Progress in Retinal and Eye Rer sarc ı. 2014; 42:44-84.

19. Shin ES, Sorenson CM, Sheibani N. Diabetes and Retin.' Vascular Dysfunction. Journal of Ophthalmic and Vision Research. 2014; 9(3):362-73.

20. Alizadeh E, Mammadzada $\mathrm{P}$, André $\mathrm{H}$. The different $\mathrm{u}$.ades of retinal and choroidal endothelial cells in response to hypoxia. Internat . nal Journal of Molecular Sciences. 2018; 19(12):3846.

21. Abbott NJ, Patabendige AAK, Dolman DE^1, 'ı",of SR, Begley DJ. Structure and function of the blood-brain barrier. Neurobiology of P:-ewue. 2010; 37(1):13-25.

22. Klaassen I, Van Noorden CJF, Schlir.y. $\left.m_{a}\right\urcorner n$ RO. Molecular basis of the inner blood-retinal barrier and its breakdown in diabetir. 1a'ular edema and other pathological conditions. Progress in Retinal and Eye Rest $\mathrm{zrcl}$. 2013; 34:19-48.

23. Armulik A, Abramsson A, Betsı. IIt> C. Endothelial/pericyte interactions. Circulation Research. 2005; 97(6):512. 25

24. Bobbie MW, Roy S, TrL: sau K, Munger SJ, Simon AM, Roy S. Reduced connexin 43 expression and its eff $\lrcorner \mathrm{Cl}$ ?n the development of vascular lesions in retinas of diabetic mice. Investigative Ophtn-Inı' Jgy and Visual Science. 2010; 51(7):3758-63.

25. Linder $\mathrm{S}$. The $\mathrm{m}$ airix zorroded: podosomes and invadopodia in extracellular matrix degradation. Trund, in Cell Biology. 2007; 17(3):107-17.

26. Bringmanr, A, ?annicke T, Grosche J, Francke M, Wiedemann P, Skatchkov SN, et al. Müller ce: : ir the healthy and diseased retina. Progress in Retinal and Eye Research. 2006; 25(4) $\because 9,124$.

27. Bri ı̣̣ı .nn A, Wiedemann P. Müller glial cells in retinal disease. Ophthalmologica. 2012; $\therefore<(\perp): 1-19$.

28. Vewman E, Reichenbach A. The Muller cell: A functional element of the retina. Trends in Neurosciences. 1996; 19(8):307-12. 
29. Dejda A, Mawambo G, Cerani A, Miloudi K, Shao Z, Daudelin JF, et al. Neuropilin-1 mediates myeloid cell chemoattraction and influences retinal neuroimmune crosstalk. Journal of Clinical Investigation. 2014; 124(11):4807-22.

30. Langmann T. Microglia activation in retinal degeneration. Journal of Leukocyte Bioloy, 2007; 81(6):1345-51.

31. Fresta CG, Fidilio A, Caruso G, Caraci F, Giblin FJ, Leggio GM, et al. A new lı maı bloodretinal barrier model based on endothelial cells, pericytes, and astrocytes. $\Gamma n_{\lambda_{1}}$ ' nadvances. 2021;162.

32. Wisniewska-Kruk J, Hoeben KA, Vogels IMC, Gaillard PJ, van Nool'`n -JF, Schlingemann $\mathrm{RO}$, et al. A novel co-culture model of the blood-retinal barrier base $i \sim n$ srimary retinal endothelial cells, pericytes and astrocytes. Experimental Eye Rese ${ }^{~}{ }^{\prime c r}$. 2012;96(1):181-90.

33. Kern TS, Antonetti DA, Smith LEH. Pathophysiology of Diabetir, ${ }^{\top} \circ$.nopathy: Contribution and Limitations of Laboratory Research. Ophthalmic researc ?. 2i)19;62(4):196-202.

34. Wang W, Lo ACY. Diabetic retinopathy: Pathophysiology and treatments. International Journal of Molecular Sciences. 2018; 19(6):1816.

35. Wu MY, Yiang GT, Lai TT, Li CJ. The oxidative stress and mitochondrial dysfunction during the pathogenesis of diabetic retinopathy. Oxidat". - Medicine and Cellular Longevity. 2018; 2018:3420187.

36. Heng LZ, Comyn O, Peto T, Tadros C, $N=$ E, $\approx$ aprasad S, et al. Diabetic retinopathy: Pathogenesis, clinical grading, manager $:=n t \ldots$ ind future developments. Diabetic Medicine. 2013; 30(6):640-50.

37. Bhagat N, Grigorian RA, Tutela A, 7 i nir. MA. Diabetic Macular Edema: Pathogenesis and Treatment. Survey of Ophthalmol igy. 2009; 54(1):1-32.

38. Durham JT, Herman IM. Microl эsr ular modifications in diabetic retinopathy. Current Diabetes Reports. 2011; 11 4): $33-64$.

39. Zhu Q, Xu X, Xia X, Gu \ Ho PCP. Role of protein kinase $C$ on the alteration of retinal endothelin-1 in strept Izu. Jcın-induced diabetic rats. Experimental Eye Research. 2005; 81(2):200-6.

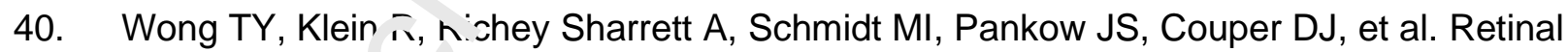
arteriolar narrnv: inc and risk of diabetes mellitus in middle-aged persons. Journal of the American M r.'.c. I Association. 2002; 287(19):2528-33.

41. Kim JH, $\mathrm{n}: m \cdot H$, Jun HO, Yu YS, Kim KW. Inhibition of protein kinase $\mathrm{C} \delta$ attenuates bloodretinal pa. :ier breakdown in diabetic retinopathy. American Journal of Pathology. 2010; $176 \div 2: \perp-17-24$.

42. 'T.' 'zuio M, Bucolo C, Leggio GM, Drago F, Govoni S, Pascale A. The PKC $/$ HuR/VEGF n: hwway in diabetic retinopathy. Biochemical Pharmacology. 2010; 80(8):1230-7.

43. McGahon MK, Dash DP, Arora A, Wall N, Dawicki J, Simpson DA, et al. Diabetes downregulates large-conductance $\mathrm{Ca} 2+$-activated potassium $\beta 1$ channel subunit in retinal arteriolar smooth muscle. Circulation Research. 2007; 100(5):703-11. 
44. Curtis TM, Gardiner TA, Stitt AW. Microvascular lesions of diabetic retinopathy: Clues towards understanding pathogenesis? Eye. 2009, 23(7):1496-508.

45. Barot M, Gokulgandhi MR, Patel S, Mitra AK. Microvascular complications and diabe'.lu retinopathy: Recent advances and future implications. Future Medicinal Chemistry. ¿¿13; 5(3):301-14.

46. Naruse K, Nakamura J, Hamada Y, Nakayama M, Chaya S, Komori T, et al. fa Nose reductase inhibition prevents glucose-induced apoptosis in cultured bovine ie... microvascular pericytes. Experimental Eye Research. 2000; 71(3):309-1ㄷ.

47. Romeo G, Liu WH, Asnaghi V, Kern TS, Lorenzi M. Activation of nuc'ea, factor-kB induced by diabetes and high glucose regulates a proapoptotic program in $r_{-\ldots}$ 'na, pericytes. Diabetes. 2002; 51(7):2241-8.

48. Benjamin LE, Hemo I, Keshet E. A plasticity window for blood $v t_{\text {. }}$, I remodelling is defined by pericyte coverage of the preformed endothelial network $c$ id is regulated by PDGF-B and VEGF. Development. 1998; 125(9):1591-8.

49. Orlidge A, D'Amore PA. Inhibition of capillary endothe' smooth muscle cells. Journal of Cell Biology. 1987, $\quad 0^{-2}, j ; 1455-62$.

50. Beltramo E, Porta M. Pericyte Loss in Diabetic F_.inopathy: Mechanisms and Consequences. Current Medicinal Chemistry. 2?13 20(26):3218-25.

51. Mannino G, Gennuso F, Giurdanella G, C - nt. $c$ Drago F, Salomone S, et al. Pericyte-like differentiation of human adipose-derived nes nchymal stem cells: An in vitro study. Pharmadvances. 2021;108.

52. Miyamoto K, Khosrof S, Bursell SE, רh in R, Murata T, Clermont AC, et al. Prevention of leukostasis and vascular leakage in si eptozotocin-induced diabetic retinopathy via intercellular adhesion molecule -1 irnibition. Proceedings of the National Academy of Sciences of the United State= 1 . „nnerica. 1999; 96(19):10836-41.

53. Yuuki T, Kanda T, Kimıra Y, ivtajima N, Tamura J, Kobayashi I, et al. Inflammatory cytokines in vitreous fluia and serum of patients with diabetic vitreoretinopathy. Journal of Diabetes and its C.om olic tions. 2001; 15(5):257-9.

54. Tang J, Kern TS. : flarımation in diabetic retinopathy. Progress in Retinal and Eye Research. 201'; ; 3C's):343-58.

55. Newton K, [iv., 'M. Signaling in innate immunity and inflammation. Cold Spring Harbor Perspective_ in Biology. 2012; 4(3):a006049.

56. Speye $C_{L}$ Ward PA. Role of endothelial chemokines and their receptors during infle:-?mution. Journal of Investigative Surgery. 2011; 24(1):18-27.

57. ip "ayue $\mathrm{AH}$, Khalil RA. Inflammatory cytokines in vascular dysfunction and vascular vi. oase. Biochemical Pharmacology. 2009; 78(6):539-52.

58. Joussen AM, Poulaki V, Le ML, Koizumi K, Esser C, Janicki H, et al. A central role for inflammation in the pathogenesis of diabetic retinopathy. FASEB Journal. 2004; 18(12):1450-2. 
59. Al-Kharashi AS. Role of oxidative stress, inflammation, hypoxia and angiogenesis in the development of diabetic retinopathy. Saudi Journal of Ophthalmology. 2018; 32(4):318-323.

60. Bayan N, Yazdanpanah N, Rezaei N. Role of toll-like receptor 4 in diabetic retinopath $\mathbf{y}$. Pharmacological research. 2022 Jan; 175:105960.

61. Son Y, Cheong Y-K, Kim N-H, Chung H-T, Kang DG, Pae H-O. Mitogen-Activat`a ?r Jtein Kinases and Reactive Oxygen Species: How Can ROS Activate MAPK Pathvca,'s! Journal of Signal Transduction. 2011; 2011:792639.

62. Cargnello M, Roux PP. Activation and Function of the MAPKs and Their Sub strates, the MAPK-Activated Protein Kinases. Microbiology and Molecular Bioloy.' h 'v/ews. 2011; 75(1):50-83.

63. Jiang B, Xu S, Hou X, Pimentel DR, Brecher P, Cohen RA. Temp “ " Activation by ERK Differentially Regulates Interleukin-1 $\beta$-indure $\iota^{\circ} \curvearrowright$ ene Expression. Journal of Biological Chemistry. 2004; 279(2):1323-9.

64. Ames A. Energy requirements of CNS cells as related tc heir function and to their vulnerability to ischemia: A commentary based on stu 1 e $=$ on retina. In: Canadian Journal of Physiology and Pharmacology. 1992; 70 Suppl:S1_ ‘'-七"

65. Dell'Omo R, Semeraro F, Bamonte G, Cifariello : Romano MR, Costagliola C. Vitreous mediators in retinal hypoxic diseases. Mediator of nflammation. 2013; 2013:935301.

66. Paternotte E, Gaucher C, Labrude P, Stc'+-: .: 'Menu P. Review: Behaviour of endothelial cells faced with hypoxia. In: Bio-Medical .." Flc. lals and Engineering. 2008; 18(4-5):295-9.

67. Wang GL, Semenza GL. General inv i. $2 r_{1}$. गnt of hypoxia-inducible factor 1 in transcriptional response to hypoxia. Proceedings $n$ ' $n \in$ National Academy of Sciences of the United States of America. 1993; 90(9):4304-8.

68. Peet DJ, Kittipassorn T, Wood D Dhidlow G, Casson RJ. HIF signalling: The eyes have it. Experimental Cell Researcl . ¿ ᄂ..7; 356(2):136-140.

69. Vadlapatla R, Vadlapuc. A, Mitra A. Hypoxia-Inducible Factor-1 (HIF-1): A Potential Target for Intervention in Ocı ıaı Veovascular Diseases. Current Drug Targets. 2013; 14(8):919-35.

70. Potente M, Gerhaı dt $\mathrm{I}$ : Curmeliet P. Basic and therapeutic aspects of angiogenesis. Cell. 2011; 146(6):87j-81.

71. Ferrara N. F of if vascular endothelial growth factor in regulation of physiological angiogene_`. ...nerican Journal of Physiology - Cell Physiology. 2001; 280(6):C1358-66.

72. Errico 'vı, Rıccioni T, Iyer S, Pisano C, Acharya KR, Persico MG, et al. Identification of placen $n_{\mathrm{s}}$ growth factor determinants for binding and activation of Flt-1 receptor. Journal of Bic IC yll al Chemistry. 2004; 279(42):43929-39.

73 ᄃ गwerchin M, Carmeliet P. Placental growth factor in cancer. Expert Opinion on Therapeutic Targets. 2014; 18(11):1339-54. 
74. Hiratsuka S, Maru Y, Okada A, Seiki M, Noda T, Shibuya M. Involvement of Flt-1 tyrosine kinase (vascular endothelial growth factor receptor-1) in pathological angiogenesis. Cancer Research. 2001; 61(3):1207-13.

75. Robinson CJ, Stringer SE. The splice variants of vascular endothelial growth factor ( $\vee^{\circ} \mathrm{GF}$ ) and their receptors. Journal of Cell Science. 2001; 114(Pt 5):853-65.

76. Fontanella C, Ongaro E, Bolzonello S, Guardascione M, Fasola G, Aprile G. C. 'nical advances in the development of novel VEGFR2 inhibitors. Annals of Trans' ttis.' ' 2014; 2(12):123.

77. Witmer AN, Blaauwgeers HG, Weich HA, Alitalo K, Vrensen GFJM, Ecringemann RO. Altered expression patterns of VEGF receptors in human diabetic, $r$,...' $\cdot z$ ind in experimental VEGF-induced retinopathy in monkey. Investigative Ophthalmoloqy an $\mathbb{1}$ Visual Science. 2002; 43(3):849-57.

78. Markovic-Mueller S, Stuttfeld E, Asthana M, Weinert T, Blivc ר S, Goldie KN, et al. Structure of the Full-length VEGFR-1 Extracellular Domain in Comrlex $w_{1}{ }^{h}$ VEGF-A. Structure. 2017; 25(2):341-352.

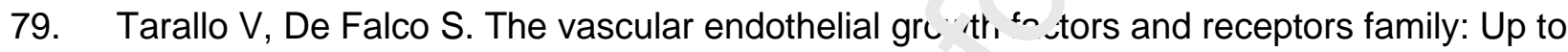
now the only target for anti-angiogenesis theranv. Inter riational Journal of Biochemistry and Cell Biology. 2015; 64:185-9.

80. Smith GA, Fearnley GW, Harrison MA, Tom' n', 7 , DC, Wheatcroft SB, Ponnambalam S. Vascular endothelial growth factors: multı _ skı,y functionality in metabolism, health and disease. Journal of Inherited Metabolic 'Js, ase. 2015; 38(4):753-63.

81. Caporale A, Martin AD, Capasso D, - $-\dot{\mathrm{C}} \mathrm{G}$, Sandomenico A, D'Andrea LD, et al. Short PIGF-derived peptides bind VEGF-. $\perp$ uld VEGFR-2 in vitro and on the surface of endothelial cells. Journal of Peptic ? S sience. 2019; ;25(5):e3146.

82. Carmeliet P, Moons L, Luttur 4, :incenti V, Compernolle V, De Mol M, et al. Synergism between vascular endothelial gr uwth factor and placental growth factor contributes to angiogenesis and plasm $m$ extravasation in pathological conditions. Nature Medicine. 2001; 7(5):575-83.

83. Autiero M, Waltenht. ^e, 1, Communi D, Kranz A, Moons L, Lambrechts D, et al. Role of PIGF in the intra- $a \cdot$ intermolecular cross talk between the VEGF receptors Flt1 and Flk1. Nature Medicin ?. 21 03; 9(7):936-43.

84. Adams RH rilte o K. Molecular regulation of angiogenesis and lymphangiogenesis. Nature Reviews Molt zular Cell Biology. 2007; 8(6):464-78.

85. Nguy $า$ Q $\cup$, De Falco S, Behar-Cohen F, Lam WC, Li X, Reichhart N, et al. Placental grc $N$ factor and its potential role in diabetic retinopathy and other ocular neovascular $\therefore$ "se c cs. Acta Ophthalmologica. 2018; 96(1):e1-e9.

86. I molada G, Del Turco C, Lattanzio R, Maestroni S, Maestroni A, Bandello F, et al. The rule of angiogenesis in the development of proliferative diabetic retinopathy: Impact of intravitreal anti-VEGF treatment. Experimental Diabetes Research. 2012; 2012:728325. 
87. Ciulla TA, Amador AG, Zinman B. Diabetic retinopathy and diabetic macular edema: Pathophysiology, screening, and novel therapies. Diabetes Care. 2003; 26(9):2653-64.

88. Roldán-Pallarés M, Rollín R, Martínez-Montero JC, Fernández-Cruz A, Bravo-Llata C, Fernández-Durango R. Immunoreactive endothelin-1 in the vitreous humor and epirt : nal membranes of patients with proliferative diabetic retinopathy. Retina. $2007 ; 27(2) 22<35$.

89. Chang W, Lajko M, Fawzi AA. Endothelin-1 is associated with fibrosis in proliic : :tive diabetic retinopathy membranes. PLoS ONE. 2018; 13(1):e0191285.

90. Friedlander M. Fibrosis and diseases of the eye. Journal of Clinical Inve tiga ion. 2007; 117(3):576-86.

91. Roy S, Amin S, Roy S. Retinal fibrosis in diabetic retinopathy. Exp rim !ntal Eye Research. 2016; 142:71-5.

92. Guidry C. The role of Müller cells in fibrocontractive retinal disor 'ers. Progress in Retinal and Eye Research. 2005; 24(1):75-86.

93. Bringmann A, Reichenbach A. Role of Muller cells in $r r^{2}$. bioscience: a journal and virtual library. $2001 ; 6: E_{1}$ )...? ?

94. Pugh CW, Ratcliffe PJ. Regulation of angiogent-is by hypoxia: Role of the HIF system. Nature Medicine. 2003; 9(6):677-84.

95. Smith LEH. Pathogenesis of retinopathy of $k " m$ tturity. Seminars in Neonatology. 2003; 8(6):469-73.

96. Wu YC, Chang CY, Kao A, Hsi B, Lee Sr: , chen YH, et al. Hypoxia-induced retinal neovascularization in zebrafish emb، $v$ s: A potential model of retinopathy of prematurity. PLoS ONE. 2015; 10(5):e012675' .

97. Hinton DR, He S, Jin ML, Barr n E Ryan SJ. Novel growth factors involved in the pathogenesis of proliferativf, v : ooretinopathy. Eye. 2002; 16(4):422-8.

98. Cui JZ, Chiu A, Maberl' D, Ma P, Samad A, Matsubara JA. Stage specificity of novel growth factor expressi. au ing development of proliferative vitreoretinopathy. Eye. 2007; 21(2):200-8.

99. Kuiper EJ, Van Nlit. "venhoven FA, de Smet MD, van Meurs JC, Tanck MW, Oliver N, et al. The angio-fibro ic $S$ ' vitch of VEGF and CTGF in proliferative diabetic retinopathy. PLoS ONE. 2008; 317 ; $\mathrm{e} 2675$.

100. Tikellis C Co . per ME, Twigg SM, Burns WC, Tolcos M. Connective Tissue Growth Factor Is Up-Re رu' 'əted in the Diabetic Retina: Amelioration by Angiotensin-Converting Enzyme Inhibitı ?. Endocrinology. 2004; 145(2):860-6.

101. $\therefore i p \vee r$ EJ, Hughes JM, Van Geest RJ, Vogels IMC, Goldschmeding R, Van Noorden CJF, $e_{\iota}$ al. Effect of VEGF-A on expression of profibrotic growth factor and extracellular matrix renes in the retina. Investigative Ophthalmology and Visual Science. 2007; 48(9):4267-76.

102. Whitcup SM, Cidlowski JA, Csaky KG, Ambati J. Pharmacology of corticosteroids for diabetic macular edema. Investigative Ophthalmology and Visual Science. 2018; 59(1):1-12. 
103. Bucolo C, Gozzo L, Longo L, Mansueto S, Vitale DC, Drago F. Long-term efficacy and safety profile of multiple injections of intravitreal dexamethasone implant to manage diabetic macular edema: A systematic review of real-world studies. Journal of pharmacological sciences. 2018 Dec;138(4):219-32.

104. Bucolo C, Drago F, Lin L-R, Reddy VN. Neuroactive steroids protect retinal piam ( nt epithelium against oxidative stress. Neuroreport. 2005 Aug;16(11):1203-7.

105. Bucolo C, Drago F. Neuroactive steroids protect retinal tissue through sigm $\mathrm{t}^{1}$, 'ceptors. Basic \& clinical pharmacology \& toxicology. 2007 Mar;100(3):214-6.

106. Tabakcı BN, Ünlü N. Corticosteroid treatment in diabetic macular eu `ma I urk Oftalmoloiji Dergisi. 2017; 47(3):156-160.

107. Chen Y, Wiesmann C, Fuh G, Li B, Christinger HW, McKay P, et a' Selection and analysis of an optimized Anti-VEGF antibody: Crystal structure of an affiri “. natured Fab in complex with antigen. Journal of Molecular Biology. 1999; 293(4):86ᄃ 81.

108. Ferrara N, Damico L, Shams N, Lowman H, Kim R. Dev spment of ranibizumab, an antivascular endothelial growth factor antigen binding frar, $\mathrm{n}_{t} \mathrm{tt}$, as therapy for neovascular agerelated macular degeneration. Retina. 2006; 26(8).? is $7 \mathrm{c}$.

109. Holash J, Davis S, Papadopoulos N, Croll SD, $\vdash_{\text {_ I }}$., Russell M, et al. VEGF-Trap: A VEGF blocker with potent antitumor effects. Proceedir, $s \mathrm{~s} i \mathrm{t}$ the National Academy of Sciences of the United States of America. 2002; 99(17)::12,03-8.

110. Rudge JS, Holash J, Hylton D, Russell M!., Tlai.ig S, Leidich R, et al. VEGF Trap complex formation measures production rates o, ' $E C, F$, providing a biomarker for predicting efficacious angiogenic blockade. Prc cf enlinys of the National Academy of Sciences of the United States of America. 2007; 1r-i(4i):18363-70.

111. Cai S, Yang Q, Li X, Zhang Y. ihe etficacy and safety of aflibercept and conbercept in diabetic macular edema. Drı^ Luvign, Development and Therapy. 2018; 12:3471-3483.

112. Papadopoulos N, Martin J, Ruun Q, Rafique A, Rosconi MP, Shi E, et al. Binding and neutralization of vascular : ndothelial growth factor (VEGF) and related ligands by VEGF Trap, ranibizumab ar $y$ be /acizumab. Angiogenesis. 2012; 15(2):171-85.

113. Lazzara F, Fidilio . Platania CBM, Giurdanella G, Salomone S, Leggio GM, et al. Aflibercept regı ıates retinal inflammation elicited by high glucose via the PIGF/ERK pathway. Bics'ce ...ical Pharmacology. 2019;168:341-51.

114. Liu K, Song ' Xu G, Ye J, Wu Z, Liu X, et al. Conbercept for Treatment of Neovascular Age-relate.' '.lacular Degeneration: Results of the Randomized Phase 3 PHOENIX Study. Amer: an juurnal of ophthalmology. 2019 Jan;197:156-67.

115. Khur N, Aziz AA, Shafi NA, Abbas T, Khanani AM. Targeting Angiopoietin in Retinal $I^{\prime} z_{-}$-ular Diseases: A Literature Review and Summary of Clinical Trials Involving Faricimab. ci.'s. 2020 Aug;9(8):1869. 
116. Heier JS, Singh RP, Wykoff CC, Csaky KG, Lai TYY, Loewenstein A, et al. THE ANGIOPOIETIN/TIE PATHWAY IN RETINAL VASCULAR DISEASES: A Review. Retina (Philadelphia, Pa). 2021 Jan;41(1):1-19.

117. Joly $S$, Dejda A, Rodriguez L, Sapieha $P$, Pernet $V$. Nogo-A inhibits vascular regene ¿tion in ischemic retinopathy. Glia. 2018 Oct;66(10):2079-93.

118. Mdzomba JB, Jordi N, Rodriguez L, Joly S, Bretzner F, Pernet V. Nogo-A inava'atıun improves visual plasticity and recovery after retinal injury. Cell death \& dise $t \leqslant=. ? 018$ Jun;9(7):727.

119. Baya Mdzomba J, Joly S, Rodriguez L, Dirani A, Lassiaz P, Behar-C ’ht.? F, et al. Nogo-A-

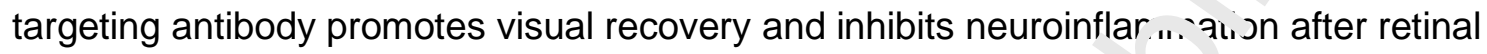
injury. Cell death \& disease. 2020 Feb;11(2):101.

120. Falavarjani KG, Nguyen QD. Adverse events and complications ¿ c',ociated with intravitreal injection of anti-VEGF agents: a review of literature. Eye (LC Idoı , England). 2013 Jul;27(7):787-94.

121. Csaky K, Do D V. Safety implications of vascular endr int 'iaı growth factor blockade for

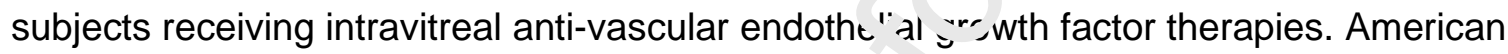
journal of ophthalmology. 2009 Nov;148(5):647-56.

122. Tolentino M. Systemic and ocular safety of intrá itrf al anti-VEGF therapies for ocular neovascular disease. Survey of ophtr al'nology. 2011;56(2):95-113.

123. Kurihara T, Westenskow PD, Bravo S, A $\cdots$;ila: E, Friedlander M. Targeted deletion of Vegfa in adult mice induces vision loss. Journc.' of Zlinical Investigation. 2012; 122(11):4213-7.

124. De Falco S, Gigante B, Persico MG - tr .cture and function of placental growth factor. Trends in Cardiovascular Medicin ?. 21 02; 12(6):241-6.

125. Rakic JM, Lambert V, Devy L. L'It', $n$ A, Carmeliet $P$, Claes $C$, et al. Placental growth factor, a member of the VEGF farr ly, ı sntributes to the development of choroidal neovascularization. Investigaı ve Ophthalmology and Visual Science. 2003; 44(7):3186-93.

126. Fischer C, Mazzone $\uparrow 1, \sim$ nnckx B, Carmeliet P. FLT1 and its ligands VEGFB and PIGF: Drug targets for anti-angi $\urcorner q_{t} \therefore$ : therapy? Nature Reviews Cancer. 2008; 8(12):942-56.

127. Tarallo V, Tudis $\sim$ L, De Falco S. A placenta growth factor 2 variant acts as dominant negative of vasi ila. endothelial growth factor $A$ by heterodimerization mechanism. American jo ir a of cancer research. 2011; 1(2):265-274.

128. De Falco $:$. The discovery of placenta growth factor and its biological activity. Experimental and $M$ sle ' lar Medicine. 2012; 44(1):1-9.

129. Ap cr.llc I, Cicatiello V, Acampora D, Tarallo V, De Falco S. Full Functional Knockout of $\therefore$ 's, ital Growth Factor by Knockin with an Inactive Variant Able to Heterodimerize with 1/r.GF-A. Cell Reports. 2018; 23(12):3635-3646.

130. Cudmore MJ, Hewett PW, Ahmad S, Wang KQ, Cai M, Al-Ani B, et al. The role of heterodimerization between VEGFR-1 and VEGFR-2 in the regulation of endothelial cell homeostasis. Nature Communications. 2012; 3:972. 
131. Tarallo V, Vesci L, Capasso O, Esposito MT, Riccioni T, Pastore L, et al. A placental growth factor variant unable to recognize Vascular Endothelial Growth Factor (VEGF) receptor-1 inhibits VEGF-dependent tumor angiogenesis via heterodimerization. Cancer Research. 2010; 70(5):1804-13.

132. Fischer C, Jonckx B, Mazzone M, Zacchigna S, Loges S, Pattarini L, et al. Anti-P GF nhibits Growth of VEGF(R)-Inhibitor-Resistant Tumors without Affecting Healthy Vesse, Lell. 2007; 131(3):463-75.

133. Gelfand M V., Hagan N, Tata A, Oh WJ, Lacoste B, Kang KT, et al. Neur'spili. $\perp$ functions as a VEGFR2 co-receptor to guide developmental angiogenesis indeper, Ner. of ligand binding. eLife. 2014; 3:e03720.

134. Lanahan A, Zhang X, Fantin A, Zhuang Z, Rivera-Molina F, Speir.1. 'af $\mathrm{C}$ K, et al. The Neuropilin 1 Cytoplasmic Domain Is Required for VEGF-A-Deponat רt Arteriogenesis. Developmental Cell. 2013; 25(2):156-68.

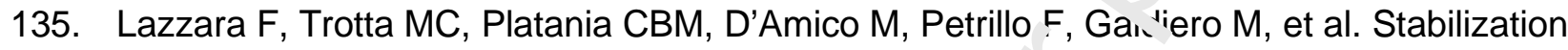
of HIF-1 $\alpha$ in Human Retinal Endothelial Cells Modulates L'vression of miRNAs and Proangiogenic Growth Factors. Frontiers in pharm?.cc ogy 2020;11:1063.

136. Tudisco L, Ragione F Della, Tarallo V, Apicella '. D'Esץ Jsito M, Matarazzo MR, et al. Epigenetic control of hypoxia inducible factor-1r. $a_{2}$ nendent expression of placental growth factor in hypoxic conditions. Epigenetics. 2011.4. $\approx \Omega \mathrm{J}-10$.

137. Yamashita T, Ohneda K, Nagano M, Miyc _ hi し, Kaneko N, Miwa Y, et al. Hypoxia-inducible transcription factor-2 $\alpha$ in endothelial cel's $s$ gulates tumor neovascularization through activation of ephrin A1. Journal of Biolngi - Chemistry. 2008; 283(27):18926-36.

138. Martinez B, Peplow P. MicroRNAs us ivmarkers of diabetic retinopathy and disease progression. Neural Regeneratinr, Re search. 2019; 14(11):1858-1869.

139. Platania CBM, Maisto R, Tre ${ }^{++} q_{1 . .2}$, D'Amico M, Rossi S, Gesualdo C, et al. Retinal and circulating miRNA expressiur putterns in diabetic retinopathy: An in silico and in vivo approach. British Jourr.?' of Pharmacology. 2019;176:2179-94.

140. Santovito D, Toto L, r 'e $\mathrm{N}$ zrdis V, Marcantonio P, D'Aloisio R, Mastropasqua A, et al.

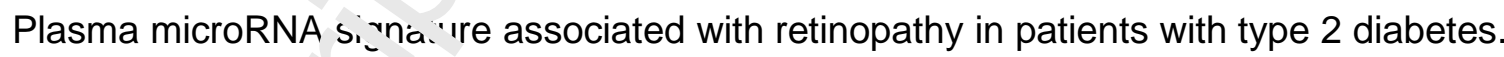
Scientific reports <??1 Feb;11(1):4136.

141. Arjamaa O, N':kit ....da M. Oxygen-dependent diseases in the retina: Role of hypoxiainducible facurs Experimental Eye Research. 2006;83:473-83.

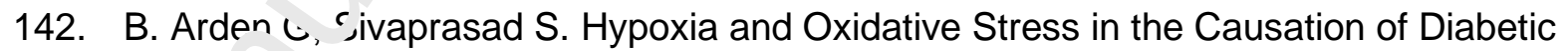
Retin . רatrı. Current Diabetes Reviews. 2012;7:291-304.

143. Ku. ir ar $\dot{A} T$, Westenskow PD, Friedlander M. Hypoxia-inducible factor (HIF)/vascular $t 7 i$ 'thelial growth factor (VEGF) signaling in the retina. Advances in Experimental Medicine a... Biology. 2014; 801:275-81.

144. Li T, Hu J, Gao F, Du X, Chen Y, Wu Q. Transcription factors regulate GPR91-mediated expression of VEGF in hypoxia-induced retinopathy. Scientific Reports. 2017; 7:45807. 
145. Shao D, He S, Ye Z, Zhu X, Sun W, Fu W, et al. Identification of potential molecular targets associated with proliferative diabetic retinopathy. BMC ophthalmology. 2020 Apr;20(1):143.

146. Liu X, Zhang Y, Liang H, Zhang $\mathrm{Y}, \mathrm{Xu} \mathrm{Y}$. microRNA-499-3p inhibits proliferation and promotes apoptosis of retinal cells in diabetic retinopathy through activation of the $\mathrm{T}\llcorner\mathrm{R}$ signaling pathway by targeting IFNA2. Gene. 2020 May; 741:144539.

147. Tang X, Dai Y, Wang X, Zeng J, Li G. MicroRNA-27a protects retinal pigment c , ,itrıelial cells under high glucose conditions by targeting TLR4. Experimental and therap $: u^{+} \leadsto$ medicine. 2018 Jul;16(1):452-8.

148. Ye E-A, Steinle JJ. miR-146a Attenuates Inflammatory Pathways Mc diá $\urcorner d$ by TLR4/NF-kB and TNF $\alpha$ to Protect Primary Human Retinal Microvascular Endothr.:-1 ¿ells Grown in High Glucose. Mediators of inflammation. 2016;2016:3958453.

149. Fletcher EL, Wang AY, Jobling Al, Rutar M V, Greferath U, Gı b, ०. al. Targeting P2X7 receptors as a means for treating retinal disease. Drug disc ery today. 2019 Aug;24(8):1598-605.

150. Bianca Maria Platania C, Drago F, Bucolo C. The P2Y I / ceptor as a new pharmacological target for retinal diseases. Biochemical pharmacolı $v$. $2 n \angle 2$ Feb;114942.

151. Tassetto M, Scialdone A, Solini A, Di Virgilio F. $\because$ P2X7 Receptor: A Promising Pharmacological Target in Diabetic Retinopathy Int arnational journal of molecular sciences. 2021 Jul;22(13).

152. Calzaferri F, Ruiz-Ruiz C, de Diego AMr, te : ascual R, Méndez-López I, Cano-Abad MF, et al. The purinergic $\mathrm{P} 2 \mathrm{X} 7$ receptor as a not 2 ntial drug target to combat neuroinflammation

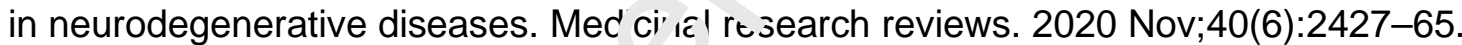

153. Pérez de Lara MJ, Avilés-Triguer 's N Guzmán-Aránguez A, Valiente-Soriano FJ, de la Villa $\mathrm{P}$, Vidal-Sanz $\mathrm{M}$, et al. Po entizl role of $\mathrm{P} 2 \mathrm{X} 7$ receptor in neurodegenerative processes in a murine model of glaucom?. ¿. ain research bulletin. 2019 Aug;150:61-74.

154. Romano GL, Amato R, Lazzaı a F, Porciatti V, Chou TH, Drago F, et al. P2X7 receptor antagonism preserves re ${ }_{1}$ ? ! ganglion cells in glaucomatous mice. Biochemical Pharmacology. 2020: $18 \mathrm{C} 114199$.

155. Platania CBM, Gi r rdarıella G, Di Paola L, Leggio GM, Drago F, Salomone S, et al. P2X7 receptor antagr nism: Implications in diabetic retinopathy. Biochemical pharmacology. 2017 Aug;138:130 3 .

156. Platania Cb.1 Lazzara F, Fidilio A, Fresta CG, Conti F, Giurdanella G, et al. Blood-retinal barrier $\mathrm{nro}_{\mathrm{\imath}} \sim$ cion against high glucose damage: The role of $\mathrm{P} 2 \mathrm{X} 7$ receptor. Biochemical pharr. эcolugy. 2019 Oct;168:249-58.

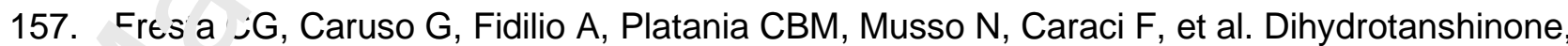
a N.tural Diterpenoid, Preserves Blood-Retinal Barrier Integrity via P2X7 Receptor. I i... 
158. Clapp C, Diaz-Lezama N, Adan-Castro E, Ramirez-Hernandez G, Moreno-Carranza B, Sarti $A C$, et al. Pharmacological blockade of the $\mathrm{P} 2 \mathrm{X} 7$ receptor reverses retinal damage in a rat model of type 1 diabetes. Acta diabetologica. 2019 Sep;56(9):1031-6. 